\title{
Can theoretical values for chest wall compliance be used in ards patients?
}

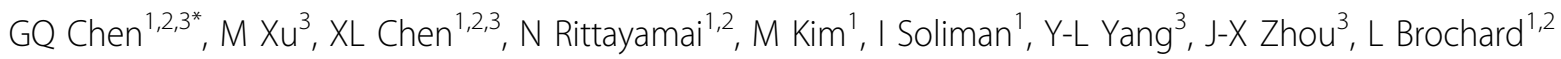

From ESICM LIVES 2015

Berlin, Germany. 3-7 October 2015

\section{Introduction}

To understand the impact of respiratory mechanics during mechanical ventilation, it is helpful to partition between the lungs and the chest wall. Esophageal pressure (Pes) is used to calculate chest wall compliance. However, esophageal pressure is not always used in the clinical arena. The value of chest wall compliance has been proposed to be estimated using $4 \%$ of the predicted value of vital capacity (VC) [1].

\section{Objectives}

This study compared the difference between the predicted and the measured value of chest wall compliance in patients with ARDS.

\section{Methods}

This observational study was conducted at St. Michael's Hospital in Toronto and Tiantan hospital in Beijing. Patients who met the Berlin definition of ARDS were

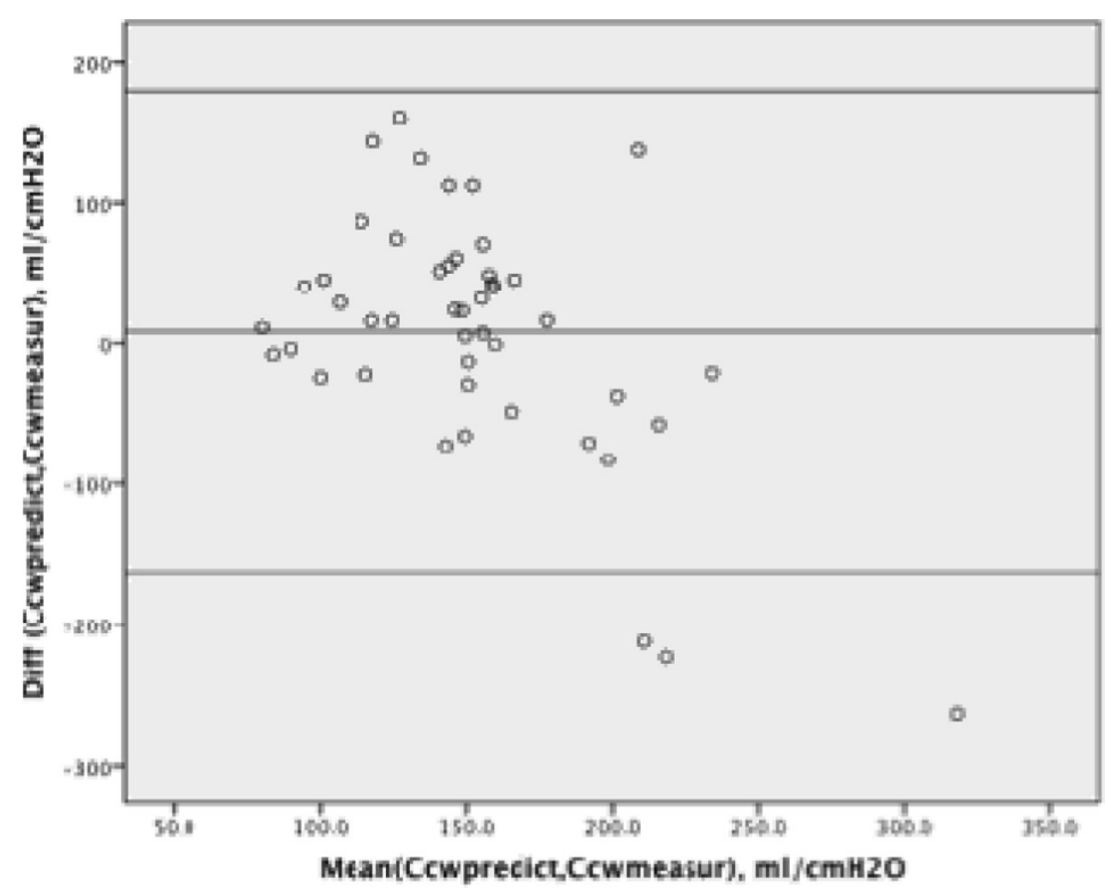

Figure 1 Bland-Altman plot.

'University of Toronto, Interdepartmental Division of Critical Care Medicine,

Toronto, Canada

Full list of author information is available at the end of the article

(C) 2015 Chen et al.; This is an Open Access article distributed under the terms of the Creative Commons Attribution License (http:// creativecommons.org/licenses/by/4.0), which permits unrestricted use, distribution, and reproduction in any medium, provided the original work is properly cited. 
eligible. Data recorded included age, height, gender, and SOFA score. Pes was measured using an esophageal balloon catheter (Cooper Surgical, United States) inflated with $1.0-\mathrm{ml}$ air via the nose or mouth. Simultaneously, we measured other ventilator parameters that were used for chest wall compliance (Ccw-measured). We used an equation to calculate the predicted $\mathrm{VC}$ according to gender, age, and height [2]: $4 \%$ of the predicted $\mathrm{VC}$ was used as the value for predicted chest wall compliance (Ccw-predicted). We used the Bland-Altman [3] method to calculate the mean difference (bias) and the standard deviation of the differences (precision) between $\mathrm{Ccw}$ predicted and $\mathrm{Ccw}$-measured.

\section{Results}

A total of 46 patients were enrolled with the following characteristics: men/women: $31 / 15$, age: $52 \pm 22$ years; $15 \%$ patients had mild ARDS, $63 \%$ patients had moderate ARDS, $22 \%$ patients had severe ARDS. They had no spontaneous breathing activity during the measurements. The mean values of the $\mathrm{Ccw}$-predicted and Ccw-measured were $156 \pm 41 \mathrm{ml} / \mathrm{cmH} 2 \mathrm{O}$ and148 \pm 78 $\mathrm{ml} / \mathrm{cmH} 2 \mathrm{O}(\mathrm{P}=0.52)$; the mean difference (bias) between Ccw-predicted and Ccw-measured was $8.4 \mathrm{ml} /$ $\mathrm{cmH} 2 \mathrm{O}$. The standard deviation of the difference (precision) was $87.4 \mathrm{ml} / \mathrm{cmH} 2 \mathrm{O}$. Figure 1 is the Bland-Altman plot showing $95 \%$ limits of agreement as $+180 \mathrm{ml} / \mathrm{cmH} 2 \mathrm{O}$ and $-163 \mathrm{ml} / \mathrm{cmH} 2 \mathrm{O}$.

\section{Conclusions}

Although the average values of predicted and observed chest wall compliance are very close (small bias), the precision of the theoretical value is poor. The predicted value could be used as a first step approach but real measurements are needed to ascertain the influence of the chest wall.

\footnotetext{
Authors' details

${ }^{1}$ University of Toronto, Interdepartmental Division of Critical Care Medicine, Toronto, Canada. ${ }^{2}$ St.Michael's Hospital, Keenan Research Centre and Li Ka Shing Insitute, Department of Critical Care, Toronto, Canada. ${ }^{3}$ Capital Medical University, Beijing Tiantan Hospital, Department of Critical Care Medicine, Beijing, China.

Published: 1 October 2015

References

1. Agostini E, Mead J: Statics of the respiratory system. In Handbook of physiology. Volume vol 1. American Physiological Society; Washington, DC; 1964:(sect 3):387-409.

2. Quanjer PH, et al: Lung volumes and forced ventilatory flows. Report Working Party Standardization of Lung Function Tests, European Community for Steel and Coal. Official Statement of the European Respiratory Society. Eur Respir J Supp/ 1993, 16:5-40.

3. Bland JM, Altman DG: Statistical methods for assessing agreement between two methods of clinical measurement. Lancet 1986, 1(8476):307-310
}

doi:10.1186/2197-425X-3-S1-A999

Cite this article as: Chen et al:: Can theoretical values for chest wall compliance be used in ards patients? Intensive Care Medicine Experimental 2015 3(Suppl 1):A999.

\section{Submit your manuscript to a SpringerOpen ${ }^{\mathcal{O}}$ journal and benefit from:}

- Convenient online submission

- Rigorous peer review

- Immediate publication on acceptance

- Open access: articles freely available online

- High visibility within the field

- Retaining the copyright to your article

Submit your next manuscript at $>$ springeropen.com 